\title{
Correction to: Study on Ultimate Compressive Strength of Aluminium-Alloy Plates and Stiffened Panels
}

\author{
Bin Liu ${ }^{1} \cdot$ Van Tuyen Doan ${ }^{1,2} \cdot$ Y. Garbatov ${ }^{3} \cdot$ Weiguo $\mathrm{Wu}^{1} \cdot$ C. Guedes Soares ${ }^{3}$
}

Published online: 25 February 2021

(C) The Author(s) 2021

\section{Correction to: Journal of Marine Science and Application (2020)}

https://doi.org/10.1007/s11804-020-00170-2

The article "Study on Ultimate Compressive Strength of Aluminium-Alloy Plates and Stiffened Panels", written by Liu, B., Doan, V.T., Garbatov, Y. et al., was originally published electronically on the publisher's internet portal on October 12, 2020 without open access. With the author(s)' decision to opt for Open Choice, the copyright of the article changed on December 4, 2020 to (C) The Authors 2020 and the article is forthwith distributed under a Creative Commons Attribution 4.0 International License, which permits use, sharing, adaptation, distribution, and reproduction in any medium or format, as long as you give appropriate credit to the original author(s) and the source, provide a link to the Creative Commons license, and indicate if changes were made. The images or other third party material in this article are included in the article's Creative Commons license, unless indicated otherwise in a credit line to the material. If material is not included in the article's Creative Commons license and your intended use is not permitted by statutory regulation or exceeds the permitted use, you will need to obtain permission directly from the copyright holder. To view a copy of this license, visit http://creativecommons.org/licenses/by/4.0/. The original article has been corrected.

Open Access This article is licensed under a Creative Commons Attribution 4.0 International License, which permits use, sharing, adaptation, distribution and reproduction in any medium or format, as long as you give appropriate credit to the original author(s) and the source, provide a link to the Creative Commons licence, and indicate if changes were made. The images or other third party material in this article are included in the article's Creative Commons licence, unless indicated otherwise in a credit line to the material. If material is not included in the article's Creative Commons licence and your intended use is not permitted by statutory regulation or exceeds the permitted use, you will need to obtain permission directly from the copyright holder. To view a copy of this licence, visit http://creativecommons.org/licenses/by/4.0/.

The online version of the original article can be found at https://doi.org/ $10.1007 / \mathrm{s} 11804-020-00170-2$

Bin Liu

liubin8502@whut.edu.cn

1 Green \& Smart River-Sea-Going Ship, Cruise and Yacht Research Centre, Wuhan University of Technology, Wuhan 430063, China

2 Faculty of Shipbuilding, Vietnam Maritime University, Haiphong, Vietnam

3 Centre for Marine Technology and Ocean Engineering (CENTEC), Instituto Superior Técnico, Universidade de Lisboa, 1049-001 Lisbon, Portugal 